\title{
Use of Technological Equipment for E-learning in Peruvian University Students in Times of Covid-19
}

\author{
https://doi.org/10.3991/ijet.v16i20.24661 \\ Yersi Luis Huamán Romaní ${ }^{1(\mathbb{})}$, José Luis Estrada Pantía ${ }^{2}$, Orlando Olivares Rivera ${ }^{2}$, \\ Efraín Rodas Guizado ${ }^{2}$, Frida Esmeralda Fuentes Bernedo ${ }^{2}$ \\ ${ }^{1}$ National Frontier University, Sullana, Perú \\ ${ }^{2}$ National José María Arguedas University, Andahuaylas, Perú \\ ylhromanilgmail.com
}

\begin{abstract}
The advance of technology grew on a large scale due to the presence of Covid-19 together with education, this growth accompanied the teaching and learning process. The transfer from face-to-face to virtual suggested choosing a teaching process, having e-learning as the most friendly. The method applied to the research is descriptive, correlational, transversal and predictive. The sample was applied randomly and voluntarily to 3532 university students from all over Peru, the sample was collected through an online survey. The results show that there are still problems with the materials they share due to the lack of reading comprehension, but by making use of communication technology and the Internet, students are able to take advantage of it and improve their teaching and learning through self-learning.
\end{abstract}

Keywords-E-learning, learning, teaching, technological equipment, ICT

\section{Introduction}

Learning and teaching in higher education centers is not exempt from the presence of Covid-19; this caused great changes for everyone, teachers had to prepare their classes to teach them online virtually and in that trance many challenges were identified to face in teaching, either asynchronously or synchronously; this change came with the unfamiliarity in pedagogical management (class preparation time, class participation, connectivity) [1], to obtain the progress of society education is the first thing to be a first quality citizen, many countries invest and are committed to the education of their country and with the emergence of ICT totally changed education in its four levels (initial, primary, secondary and university), because of Covid-19 the traditional teaching was left to oblivion to accept e-learning teaching in all educational centers worldwide, whose only solution to this problem was online learning with various methods such as e-learning having as a consequence the saturation of the internet line [2], with the emergence of Covid-19 emerged the teaching in the online version, giving rise to online surveys to investigate the challenges and characteristics of teaching and learning [3]. 
Education in the world had a resounding change by the presence of Covid-19, demanding that education in the world is online, which change affected students and teachers with the emergence of multiple applications for the learning process where much difference was noticed with the teaching of "traditional" way, but the emotion is perceived more in students [4]; with this advance had to adapt to the new strategies of online education and one of these applications is e-learning whose use grew exponentially because of its easy access [5], this spread of Covid-19 brought opportunities and challenges at all levels of education, even more so in higher education whose progress in virtual education was little by little, university education not only offers extensive knowledge, but also helps to train people with skills and fundamental aspects that will make them face life; Therefore, this virtual teaching does not help in these points and should return to the classroom immediately and from there propose a hybrid learning teaching (virtual and face-to-face), since virtual teaching has many benefits and improvements for learning [6]. One of the methods with the greatest impact was e-learning in higher level students, due to the help and relationship of their thinking and learning skills; the e-learning model eliminated cultural and social barriers [7].

In these times education is the most affected having to face challenges such as learning and teaching pursued by technology, which had to be addressed first in all educational institutions, thanks to technology and e-learning method it was possible to continue with education virtually with highly significant effects [8], in virtual teaching teachers seek to visualize facial expressions to be able to "judge" the learned of students to then replace the strategies in a timely manner if necessary; for this purpose different facial recognition programs were used [9], the greatest attention in education were the learning systems with the e-learning method at all levels of education, the pandemic brought more training for teachers on topics such as ICT for its application in their teaching and many managers stopped traveling for their meetings, as the e-learning methodology was imposed elegantly to organize meetings, tasks, jobs and share all kinds of knowledge and experiences about the learning and teaching process [10]. Elearning has facilitated the study and has broken barriers, its efficiency of the method depends only on the technology and the quality of the internet, but still there are places where there is no access to these technologies because of the poor quality of internet so many students from different universities could not study [11], autonomous learning was the most pronounced concept in these times of Covid-19 due to the learning and teaching with the e-learning method, the negative consequences are the great desertions, low performance and repetition of the course because the university students lacked propaedeutic training to be more autonomous in their learning process [12], as well as a survey of teachers on attitudes, competencies and measures of digital technologies in education which resulted in very high attitudes towards digital technology but low attitudes towards them [13].

As well as the e-learning environment there is the Flipped-learning which is a virtual learning model, whose application was to strengthen the student-teacher relationship, educational practice and especially to evaluate this model; reaching the conclusion that the Flipped test under an e-learning approach improves the training of students in a positive way [14]. The University of Medellin together with other companies and local government investigated through learning platforms the learning styles of university 
students using artificial intelligence for this Kolb's learning styles were used [15], elearning is practiced in universities thanks to ICT as the first class teaching worldwide, it is applied in all courses especially in mathematics forgetting the traditional class and making use of digital technology e-learning is gradually imposed on the old methodologies [16]. This pandemic of Covid-19 promoted virtual teaching and learning environments at all levels, as well as in higher education it was adapted from cultures, policies and inclusive practices to reflect its management and application; this process was done with professionals from the University of Manchester whose result was a guide with information in a quantitative and qualitative way for the development of virtual environments with e-learning [17]. The face-to-face university courses became online courses due to Covid-19, even mathematics courses had to use various technologies for teaching and learning, e-learning whose environment helped positively with support of virtual platforms in academic performance in many universities, resulting in significantly positive mathematics learning and performance [18] Positive changes were seen in teachers after receiving trainings in digital competencies topics, whose effects were greater use of digital resources, professional commitment, improvements in the quality of evaluation, better activities in teaching and in students empowerment was noticed; All these results were thanks to the fluid communication and cooperation of the institution which provided them with digital technologies with the sole purpose of improving learning and teaching [19].

The evaluations and/or written tests in times of Covid-19 were left to oblivion, moving to online evaluation with different instruments and methodologies; which leads to reconsider the type of evaluation that is done at the higher level, taking into consideration that the use of the rubric and the simulated exam focus a better evaluation instrument and thus students can be prepared for the final exam, which resulted positively in each of them and generated a good performance and academic development [20], in fact there is the bias of choice between the target population and the online population when conducting online surveys, as it also reduces expenses, effort and time, these surveys as the online evaluations would affect the level of reliability because it would have to resort to Big Data for being large populations and use mathematical models to improve the estimates, the promising algorithm is machine learning which offers voluntary bias with better approximations [21], artificial intelligence was also applied with the sole purpose of improving the assessments that were used in the Microsoft Teams platform, this thanks to the neural network that was used to be able to capture the faces and notice the facial emotions of the students, to implement the respective solutions in learning - teaching [22]. As the assessments are being conducted online we sought to relate the effects between facial expressions and teaching, this was done with tensorflow software, whose results at $98.76 \%$ were able to identify facial expressions in their different forms (happy, sad, fear, surprise among others), this model positively helps the teacher to understand and identify the level of learning in classes and student evaluations, with this model we want to improve and support the quality of learning and teaching [23]. The validation of the Online Self-Regulated Learning Questionnaire (OSLQ) instrument, which measures the learning provided by platforms, obtained a very reliable Cronbach's Alpha, which means that this OSLQ instrument will support the development of the student's motivations, cognitive skills and behavior [24]. 
The educational programs that are currently used is thanks to the presence of Covid19 , universities had to digitalize for this they had to rely on digital transformation using different programs to achieve good teaching and learning [25], higher education in these times with online courses and online teaching form a single element to seek the quality of education, this union occurred after having closed schools, colleges, institutes and universities worldwide as a result of Covid-19, the University of Turin used a model "Start@unito" which is a digital learning environment to learn about the level of teaching that it experienced [26], other universities used patterns to measure the behavior of students and teachers on the learning management system (LMS) with clustering techniques and sequential analysis resulting in five types of which the most prominent was collaboration, communication and assignment [27].

The acceptance of the learning system with e-learning has exceeded the expectations of students, but little is known about the factors that motivate their acceptance, for this the technology acceptance model (TAM) was used, which uses social networks to motivate them and make an exchange of knowledge whose results were significantly positive and the factors were the usefulness and ease of use [28], the Universidad Politécnico Gran Colombiano uses collaborative work skills so that students can interact and thus find different opinions, provide input, solve mathematical problems, generate strengthening in various aspects and learn different types of learning; This methodology was used in mathematics courses and gave good results [29] and despite having a large amount of research with reference to virtual learning tools, the benefits and positive factors for education with these environments still persist, but these investigations are being done in a meta-analytical way whose contributions are very valuable for education [30].

The effectiveness and advantage of using blended learning in universities are positive, as well as "blended learning" or learning such as offline and e-learning combined with various types of digital resources are significantly valuable for teaching and learning [31], student achievement is distinguished once familiar with an e-learning environment [32].

The satisfaction of online classes that students had at first was discouraging, but thanks to the adaptation in a very accelerated way so as not to affect the dream of every student, "to be a professional" led to research on the satisfaction of online classes later, whose factors of greater weight was the teaching method of teachers, which was imposed against the curriculum and the learning environment itself [33], e-learning has multidimensional form relationships such as metacognitive strategies incur in e-learning acceptance and satisfaction, but self-efficacy affects satisfaction, so e-learning platforms have to be repowered in e-learning [34].

The results of the courses that were dictated online previously we looked at them from "far away", because we did not know how it worked; but in our time everyone, absolutely everyone is receiving the classes in a non-presential way and using learning environments, teaching platforms among others that have better results of the traditional method; existing full satisfaction for these pedagogical methods in higher education [35]. 


\section{Justification and objectives of the study}

In these times of Covid-19 the need for the internet was like daily bread, without this medium it would not have been possible to reach the deepest corners, thanks to this tool many university students continued their studies and teachers had the opportunity to have scientific literature at hand to analyze scientific research as the highlight of the elearning method and others for teaching and learning [36], e-learning has a purely virtual training approach, whose evolution is given thanks to Covid-19 for its application in the educational environment, the application and acceptance in educational centers is due to the process of learning and teaching [37].

In order to develop this research, the objectives were formulated as to know the expectations of e-learning and how university students in Peru were facing the learning methods in times of Covid-19.

- To analyze descriptively the demographic characteristics.

- To analyze the distribution of the types and uses of the technological devices used in the courses during the Covid-19 pandemic

\section{$3 \quad$ Method}

\subsection{Research design}

This is a descriptive, correlational, cross-sectional and predictive quantitative research design [38].

\subsection{Sample}

A total of 3532 university students from all over the country were surveyed, between $44.71 \%$ female and $55.29 \%$ male, distributed according to age from 16 to 20 years (49.43\%); between 20 and 25 years $(42.78 \%)$; between 25 and 30 years $(5.55 \%)$ and more than 30 years $(2.24 \%)$ from national universities $56.43 \%$ and private universities $43.57 \%$, who were studying from the first cycle to the tenth cycle $(17.67 \% ; 13.05 \%$; $16.02 \% ; 10.14 \% ; 4.61 \% ; 12.8 \% ; 5.8 \% ; 7.79 \% ; 4.45 \%$ and $7.67 \%$ respectively), the careers were classified in four areas such as Sciences $2.92 \%$, Engineering $35.25 \%$, Health Sciences $1874 \%$ and Social Sciences $43.09 \%$, the respondents were randomly and voluntarily through an online survey for which the google form was used, the survey was conducted during the first three weeks of the month of May.

\subsection{Instrument}

The validated questionnaire [39] was used with a Cronbach's alpha of .868, which guarantees to carry out other research, this measurement instrument is composed of 11 questions, which aim to measure e-learning in Peruvian university students during the Covid-19 period, this measurement instrument has the format of a five-point Likert- 
type scale, one point (1) more negative rating and five points (5) more positive rating; this measurement instrument achieved adequate scores in its original validation development, but this instrument (questionnaire) was tested in a Peruvian context with the 3532 university students chosen randomly and voluntarily. The sociodemographic variable was also surveyed using the Likert scale.

The exploratory factor with varimax rotation was used for data analysis. Several tests were tested to make the respective comparisons such as Bartlett's sphericity with the Chi-square approximation (2884.955) with gl. 21 and Sig. 0.000 and the Kaiser-MeyerOlkin test (0.676) with the sole purpose of adjusting the sample, resulting in optimal results in the tests. In all of them, relevant results were achieved for the internal consistency of the questionnaire.

\subsection{Procedure and data analysis}

The research began in the month of May, and students from national and private universities throughout the country were surveyed by distributing the link to the survey among teachers and students from the different universities in Peru, in a randomized manner, where they were first informed of the objective of the research and consented to give their authorization to make their answers public once the research was completed; all considerations of good research practices and ethics were respected, which were established in the Declaration of Helsinki.

This "new" and novel approach to e-learning in Peruvian university students has a positive acceptance in spite of the difficulties that arose at the beginning of the applications, since it surprised the entire educational environment from the initial level, primary, secondary through university level and possibly reaching postgraduate level.

Once all the information was downloaded, we proceeded to its respective analysis in order to then interpret and conclude with the most relevant information for the scientific community and thus answer our research objectives.

The SPSS version 25 program was used for data analysis, verifying the assumed linearity, normality, independence, residual analysis, homoscedasticity and non-collinearity.

\section{$4 \quad$ Results}

The results show in Figure 1 where it is observed that the technological equipment of greater use to listen to their classes in university students is the cell phone and personal computers or Tablet, then in Figure 2 we have the result of the means by which the student communicates with the teacher, observing that the most used means is WhatsApp and Google Meet; in Figure 3 we have the results of the type of technological equipment which is used for their academic work and in Figure 4 we have the results of the dedication of hours used by the university student to perform academic work.

Figure 1 shows the type of technological device used in the courses during the Covid-19 pandemic to receive their classes, obtaining the following results: cell phones 
(D4) in $72.1 \%$ are the most used to be able to receive the respective classes; followed by personal computers or Tablet (D3) with 63. 7\%; virtual learning systems (D5) with $39.8 \%$; video conferencing systems (D2) with 29.8\%; digital video cameras (D6) with $20.7 \%$, digital photo cameras (D7) with $20.6 \%$ and finally projection systems (D1) with $10.2 \%$.

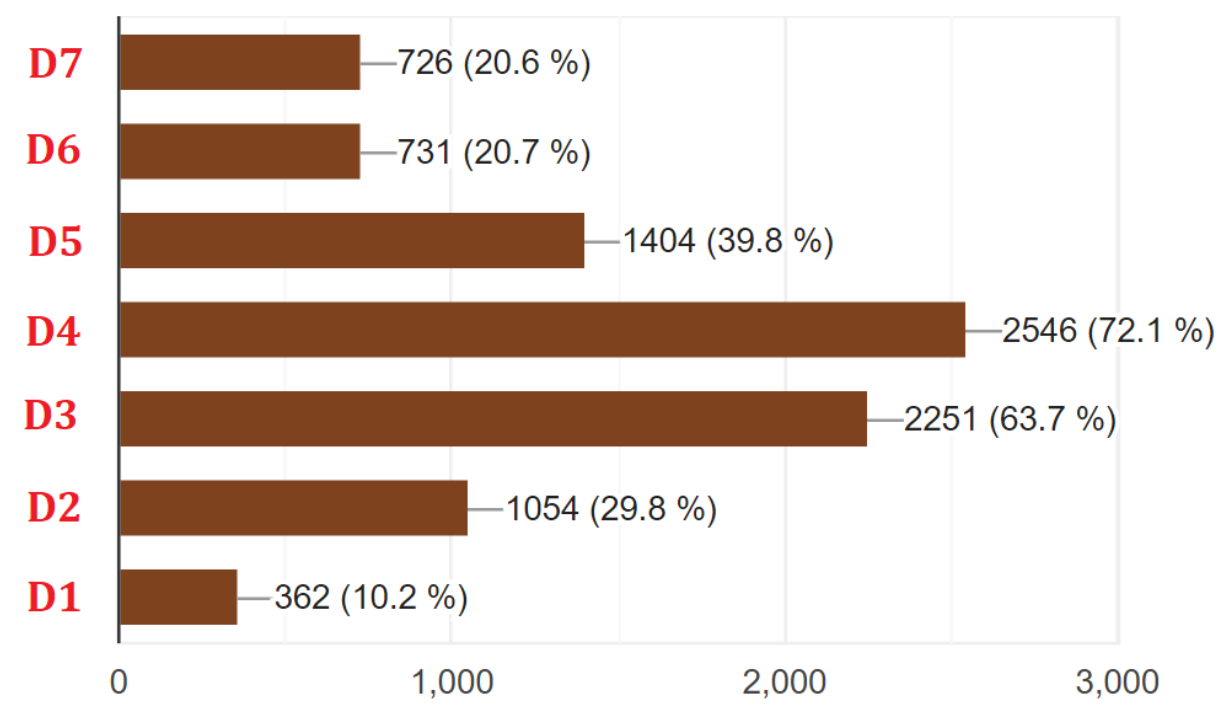

Fig. 1. Distribution of the types of technological devices used in the courses during the Covid19 pandemic.

Figure 2 shows the results of how students communicated with their teachers (student to teacher); with $71.2 \%$ communication is via WhatsApp (M4), with $55.2 \%$ Google Meet (M2), with 47.3\% Email, e-learning/virtual teaching platforms (M6), with $44.3 \%$ Email (M7), with 44.2\% Zoom (M3), with $10.4 \%$ other means of communication and with 9.2\% Microsoft Teams (M5). 


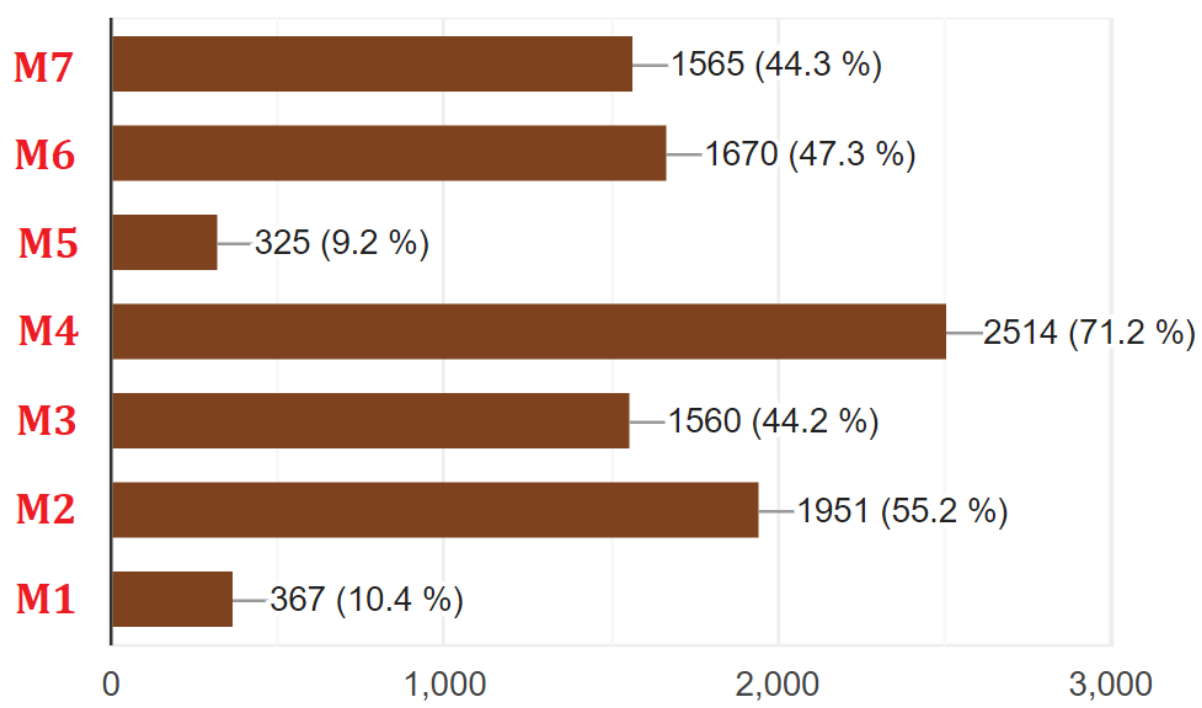

Fig. 2. Distribution of how students have communicated with their professors

Figure 3, shows the results of the types of technological equipment used by university students to receive their respective classes, resulting that $70.1 \%$ use Laptos (E3), 44.4\% use Smart Phones (E1), 27.2\% use Desktop Computers (E4) and only 8.9\% use Ipads or tablets (E2).

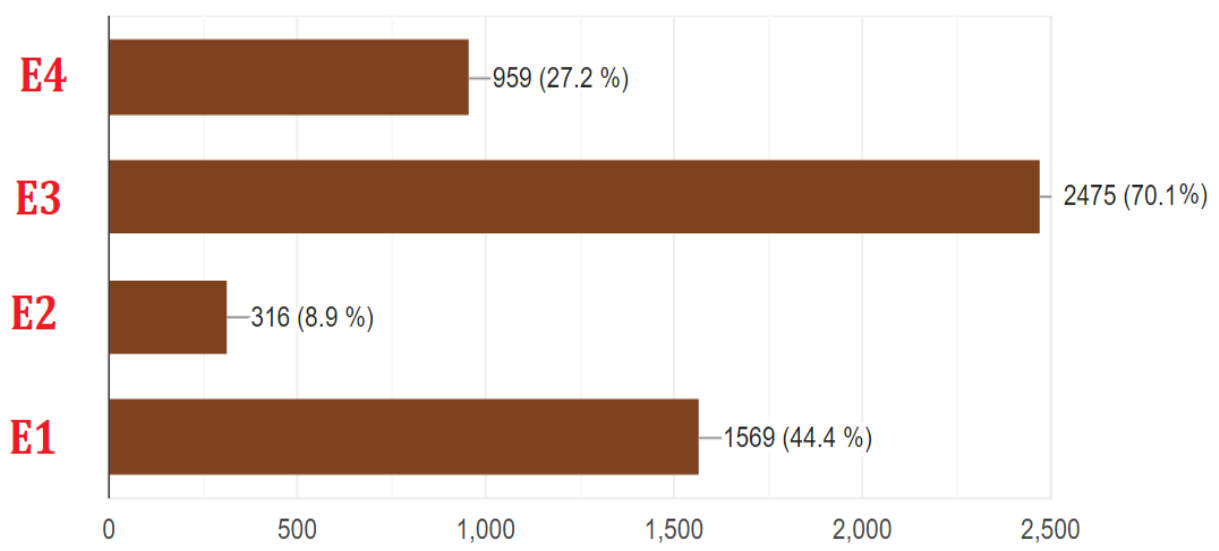

Fig. 3. Distribution of the type of technological equipment used by university students.

Figure 4 shows the results of how many hours a day university students dedicate to class work, showing that $48.7 \%$ dedicate between 3 to 5 hours, $30.2 \%$ dedicate between 6 to 10 hours, $14.1 \%$ dedicate between 1 to 2 hours and only $7 \%$ dedicate more than 10 hours to class work. 


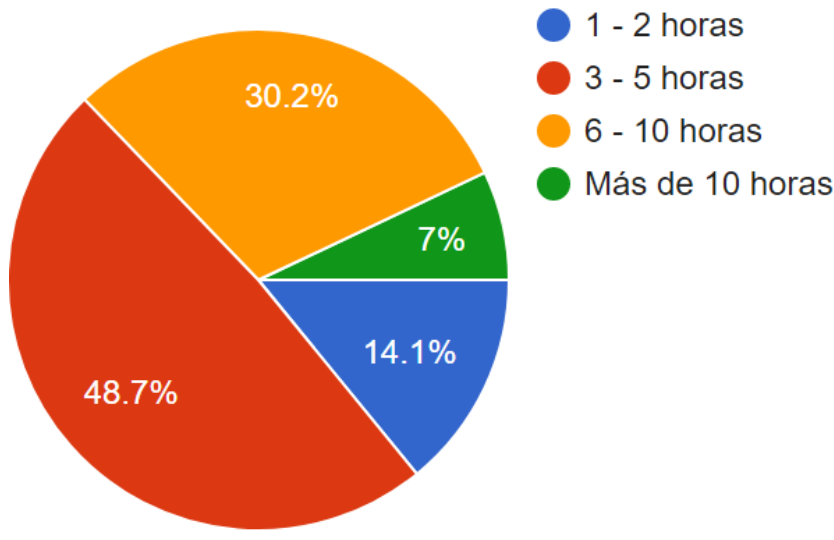

Fig. 4. Distribution of the dedication of hours to carry out the work.

Table 1 shows the results of the descriptive statistics where the highest mean is shown in the difficulty of understanding the contents, with a variance of 8.3222 and a squared multiple correlation of .146 and the lowest mean score is shown when the student consults the course materials at any time of the day, it does not help their understanding, with variance of 7.899 and a squared multiple correlation of .136.

Table 1. Questionnaire descriptive statistics

\begin{tabular}{|l|c|c|c|c|}
\hline & $\begin{array}{c}\text { Scale mean if } \\
\text { the item is } \\
\text { suppressed }\end{array}$ & $\begin{array}{c}\text { Scale vari- } \\
\text { ance if item } \\
\text { is suppressed }\end{array}$ & $\begin{array}{c}\text { Scale vari- } \\
\text { ance if item } \\
\text { is suppressed }\end{array}$ & $\begin{array}{c}\text { Squared multi- } \\
\text { ple correlation }\end{array}$ \\
\hline $\begin{array}{l}\text { Is the use of E-Learning (the teaching and } \\
\text { learning we receive online, i.e. through the } \\
\text { Internet and technology) the main diffi- } \\
\text { culty you have faced? }\end{array}$ & 23,3553 & 7,513 &, 266 &, 158 \\
\hline $\begin{array}{l}\text { When you study a course, is understanding } \\
\text { the content your greatest difficulty? }\end{array}$ & 23,8916 & 8,322 &, 082 &, 146 \\
\hline $\begin{array}{l}\text { Referring back to the course materials at } \\
\text { any time during the day significantly aids } \\
\text { in their comprehension }\end{array}$ & 23,0654 & 7,899 &, 297 &, 136 \\
\hline $\begin{array}{l}\text { The PowerPoint presentation significantly } \\
\text { aids your understanding of the course. }\end{array}$ & 23,0578 & 7,490 &, 378 &, 269 \\
\hline $\begin{array}{l}\text { Online meetings (i.e. Zoom, MS Teams, } \\
\text { GoogleMeet, etc...) significantly help your } \\
\text { understanding. }\end{array}$ & 23,2537 & 7,681 &, 293 &, 308 \\
\hline $\begin{array}{l}\text { Your teachers have responded to your } \\
\text { comments and questions. }\end{array}$ & 23,1645 & 7,917 &, 270 &, 193 \\
\hline $\begin{array}{l}\text { Internet speed is the main online difficulty } \\
\text { encountered }\end{array}$ & 22,8522 & 7,871 &, 212 &, 077 \\
\hline
\end{tabular}

Table 2 shows the means of each question, obtaining the highest score 4.2545 in question 7 (P7) where Internet speed is the main online difficulty they have faced, with a standard deviation of 0.92790 and the lowest mean was in question 2 (P2) where they 
state that understanding the content is their greatest difficulty, with a standard deviation of 1.01566; there is a relationship between the same variables.

Table 2. Relationship analysis

\begin{tabular}{|l|c|c|c|c|c|c|c|c|c|}
\hline & Media & D.E. & P1 & P2 & P3 & P4 & P5 & P6 & P7 \\
\hline P1 & 3.7514 & 0.95964 & & & & & & & \\
\hline P2 & 3.2152 & 1.01566 & 0.342 & & & & & & \\
\hline P3 & 4.0413 & 0.78789 & 0.071 & -0.022 & & & & & \\
\hline P4 & 4.0490 & 0.81416 & 0.097 & -0.048 & 0.286 & & & & \\
\hline P5 & 3.8531 & 0.86545 & 0.013 & -0.132 & 0.281 & 0.468 & & & \\
\hline P6 & 3.9422 & 0.81930 & 0.030 & -0.088 & 0.259 & 0.308 & 0.392 & & \\
\hline P7 & 4.2545 & 0.92790 & 0.229 & 0.162 & 0.108 & 0.114 & 0.011 & 0.028 & \\
\hline
\end{tabular}

Note: P1: E-Learning usage is the main difficulty you have faced; P2: When you study a course, is understanding the content your biggest difficulty; P3: Referring back to the course materials at any time of the day significantly helps your understanding; P4: PowerPoint presentation significantly helps your understanding of the course; P5: Online meetings (i.e. Zoom, MS Teams, Googlemeet, etc.. ..) significantly help your understanding; P6: Your professors have responded to your comments and questions; and P7: Internet speed is the main online difficulty you have faced.

\section{Discussion}

In the educational environment e-learning is the most accepted at all levels of education for its easy access and friendly environment, leaving aside the teaching and learning in a traditional way to be able to deal with technology, information and communication both teachers and students immediately, at the beginning of the pandemic of Covid-19 has left us no time to be able to train and to be able to face education with all the tools and environment for teaching and learning.

The results of the data analysis reveal that there is a dominance (almost nothing) of the male sex in the sample, the age of the university students predominates with less than 25 with a high percentage of $92.21 \%$, the student population at the time of the survey has the Social Sciences (Education, Law, Accounting, Administration, among others) and Engineering (Civil, Systems, Environmental, Industrial, Agroindustrial, among others) as the most populated careers; it is observed that the number of university students at the time of the survey are dispersed and there is no homogeneity in the study cycles, despite the fact that year after year the same number of students enter and with respect to the type of university there is a good number of respondents compared to many surveys conducted previously, this is due to the ease that students have to make use of their respective cell phones and be able to respond immediately to the online survey.

Within the results we have that the technological equipment of greater use to listen to their classes in university students is the cell phone and personal computers, remembering that when this pandemic began all universities implemented to students according to the SISFOH program by provision of the Peruvian State, thus delivering both Chips cards for internet use and from the cell phone to share internet to a laptop or 
Paper-Use of Technological Equipment for E-learning in Peruvian University Students in Times of...

computer and thus listen to the respective classes, as were also delivered in some universities Tablets; The students were able to answer more than one option because most of them combine cell phones and computers.

While the most used means of communication is the application of a social network called WhatsApp, whose application is not approved for official use at the university level, but even so it is used more frequently for its ease, access and daily use of university students; in second place, is the Google Meet this is because it grew exponentially access to institutional emails where is the Google Meet and is easily accessible and "official" use for universities; also in this question students could answer more than one option.

\section{Conclusion}

The use and application of the most used method in these times e-learning in the teaching and learning process was very successful and successful, university students value positively all teaching and learning environments and especially the e-learning method.

Due to the socio-sanitary situation, it has not been possible to request the respective permissions from the different universities to obtain as many samples as possible. As for future research that could be promoted would be to generate devices which would serve as radio listening channels so as not to depend on the internet in very remote places and to continue with the teaching and learning process in university students, allowing them to continue and finish their university studies and to go out professionally for the good of their locality and to face society in a responsible way. The theoretical and practical implications in education of the teaching and learning process are very significant with the e-learning method not only for students but also for teachers and anyone who makes use of this method. The e-learning method combined with other technologies can have different applications for the good of education in its learning and teaching process; interacting synchronously and/or asynchronously. Finally, it was demonstrated with multiple researches that the e-learning method is of great importance and brings good positive results for education.

\section{$7 \quad$ References}

[1] Zhao, X., Kung, M., Cai, L. (2021) How Instructors Initially Viewed Teaching Online in Higher Education in the UK During the COVID-19 Pandemic. Lecture Notes in Computer Science (including subseries Lecture Notes in Artificial Intelligence and Lecture Notes in Bioinformatics), 12511 LNCS, pp. 277-286. https://doi.org/10.1007/978-3-030-66906-5 26

[2] Khalil, M.I., Humayun, M., Jhanjhi, N.Z. (2021) COVID-19 Impact on Educational System Globally. Studies in Systems, Decision and Control, 324, pp. 257-269. https://doi.org/ $\underline{10.1007 / 978-3-030-60039-6 \quad 13}$

[3] Kong, X., Liu, N., Zhang, M., Xu, M. (2021) Analysis of online college teaching data before and after the COVID-19 epidemic. Qinghua Daxue Xuebao/Journal of Tsinghua University, 61 (2), pp. 104-116. https://doi.org/10.16511/j.cnki.qhdxxb.2020.21.017 
Paper-Use of Technological Equipment for E-learning in Peruvian University Students in Times of...

[4] Bakonyi, V., Illes, Z., Verma, C. (2021) Key element in online education to activate students with real-time tolos. Proceedings of 2 nd International Conference on Computation, Automation and Knowledge Management, ICCAKM 2021, art. no. 9357714, pp. 326-331. https://doi.org/10.1109/ICCAKM50778.2021.9357714

[5] Huamán-Romaní, Y. L., Moreno-Guerrero, A. J., Marín-Marín, J. A., \& López-Belmonte, J. (2021). The e-Learning Method for Teaching Mathematical Content in the COVID-19 Era. 12(6), 2045-2057. https://doi.org/10.17762/turcomat.v12i6.4809

[6] Leo, S., Alsharari, N.M., Abbas, J., Alshurideh, M.T. (2021) From Offline to Online Learning: A Qualitative Study of Challenges and Opportunities as a Response to the COVID-19 Pandemic in the UAE Higher Education Context. Studies in Systems, Decision and Control, 334, pp. 203-217. https://doi.org/10.1007/978-3-030-67151-8 12

[7] Rababa, N. (2021) The effect of e-learning in developing high thinking skills. International Journal of Data and Network Science, 5 (1), pp. 43-46. https://doi.org/10.5267/j.ijdns. 2020.11.004

[8] Agarwal, A., Hasan, R., Naidu, V.R., Saqib, M., Srinivas, S., Jesrani, K. (2021) Educational association mining on the use of media platforms for e-learning. Proceedings of 2nd International Conference on Computation, Automation and Knowledge Management, ICCAKM 2021, art. no. 9357727, pp. 309-314. https://doi.org/10.1109/ICCAKM50778.2021.9357727

[9] Cai, Y., Zhao, T. (2021) Performance analysis of distance teaching classroom based on machine learning and virtual reality. Journal of Intelligent and Fuzzy Systems, 40 (2), pp. 2157 2167. https://doi.org/10.3233/JIFS-189215

[10] Giannakos, M.N., Mikalef, P., Pappas, I.O. (2021) Systematic Literature Review of ELearning Capabilities to Enhance Organizational Learning. Information Systems Frontiers. https://doi.org/10.1007/s10796-020-10097-2

[11] Johnson, J.B., Reddy, P., Chand, R., Naiker, M. (2021) Attitudes and awareness of regional Pacific Island students towards e-learning. International Journal of Educational Technology in Higher Education, 18 (1), art. no. 13. https://doi.org/10.1186/s41239-021-00248-Z

[12] Saltos, W.R.F., Maldonado, C.G. (2019) Predictive models for the detection of problems in autonomous learning in higher education students virtual modality. Iberian Conference on Information Systems and Technologies, CISTI, 2019-June, art. no. 8760605. https://doi.org/10.23919/cisti.2019.8760605

[13] Štemberger, T., Čotar, S. (2021) Attitudes Towards using Digital Technologies in Education as an Important Factor in Developing Digital Competence: The Case of Slovenian Student Teachers. International Journal of Emerging Technologies in Learning (iJET). Vol 16, No 14 págs. 83-98. https://doi.org/10.3991/ijet.v16i14.22649

[14] Feo, R.L., Hernández, H.A. (2020) Evaluate the flipped learning model in an E -learning learning environment. Meta: Avaliacao, 23 (36), pp. 571-600. https://doi.org/10.22347/ $\underline{2175-2753 \mathrm{v} 12 \mathrm{i} 36.2575}$

Arango-Medina, D., Gonzalez-Palacio, L., Torres-Bedoya, D., Garcia-Giraldo, J., Cuatindioy, J., Gonzalez-Palacio, M., Luna, M., Garcia-Garzon, J.Y.J., Pabon, H.J.O., Echeverri, J., Bedoya, J. (2020) Virtual platforms that recognize learning styles and allow the deployment of Problem Based Learning methodology -ABP. Iberian Conference on Information Systems and Technologies, CISTI, 2020-June, art. no. 9141087. https://doi.org/10.23919/ cisti49556.2020.9141087

[16] Alotaibi, S.S., Kumar, T. (2019) Promoting teaching and learning performance in mathematics classroom through e-learning. Opcion, 35 (Special Issue 19), pp. 2363-2378.

[17] Sánchez, A.M.H., Ainscow, M. (2020) Desarrollo de una guía para promover un e-learning inclusivo en educación superior. Perfiles Educativos, 42 (168), pp. 60-75. https://doi.org/ $\underline{10.22201 / \text { iisue. } 24486167 \mathrm{e} .2020 .168 .58990}$ 
Paper-Use of Technological Equipment for E-learning in Peruvian University Students in Times of...

[18] Wang, H. (2021) What works and what does not: A reflective practice on an online mathematics class. Mathematics Teaching-Research Journal, 13 (1), pp. 16-30.

[19] Reisoğlu, İ. (2021) How Does Digital Competence Training Affect Teachers' Professional Development and Activities? Technology, Knowledge and Learning. https://doi.org/ 10.1007/s10758-021-09501-w

[20] Álvarez-Herrero, J.-F. (2020) The power of anticipation in assessment: Mock exams and rubrics in Higher Education. Aloma, 38 (2), pp. 51-58. https://doi.org/10.51698/ALOMA $.2020 .38 .2 .51-58$

[21] Ferri-García, R., Castro-Martín, L., Rueda, M.D.M. (2021) Evaluating Machine Learning methods for estimation in online surveys with superpopulation modeling. Mathematics and Computers in Simulation, 186, pp. 19-28. https://doi.org/10.1016/i.matcom.2020.03.005

[22] Ilic, V., Batic, D., Mirkovic, M., Vukmirovic, S., Culibrk, D., Bosakov, G., Popovic, I. (2021). Automatic Emotion Detection as a Teaching Aid in Online Knowledge Assessment. 2021 20th International Symposium INFOTEH-JAHORINA, INFOTEH 2021 https://doi.org/10.1109/infoteh51037.2021.9400699

[23] Zhan, Z., Shen, T., Jin, L., Huang, F., Xu, H. (2021) Research on Evaluation of Online Teaching Effect based on Deep Learning Technology IAEAC 2021 - IEEE 5th Advanced Information Technology, Electronic and Automation Control Conference, art. no. 9390652, pp. 249-253. https://doi.org/10.1109/iaeac50856.2021.9390652

Pinto-Santuber, C., Ortiz-Salgado, R., Mendoza, C.L.M., Alvarado, M.Y., Sanz, P.L. (2020) Online Self-regulated Learning Questionnaire (OSLQ): Study of validity and reliability of the Spanish versión. Estudios Pedagógicos, 46 (2), pp. 251-266. https://doi.org/10.4067/ s0718-07052020000200251

[25] Mora, H.L., Sanchez, P.P. (2020) Digital Transformation in Higher Education Institutions with Business Process Management. Robotic Process Automation mediation model Iberian Conference on Information Systems and Technologies, CISTI, 2020-June, art. no. 9140851. https://doi.org/10.23919/cisti49556.2020.9140851

[26] Bruschi, B., Marchisio, M., Sacchet, M. (2021). Teaching in Higher Education with the Support of Start@Unito During Covid-19 Pandemic. Communications in Computer and Information Science, 1344, pp. 187-198. https://doi.org/10.1007/978-3-030-67435-9_15

[27] Chien-Yuan S., Yu-Hang L., Cheng-Huan C. (2021) Understanding the Behavioural Patterns of University Teachers Toward Using a Learning Management System. International Journal of Emerging Technologies in Learning (iJET). Vol 16, No 14 págs. 129-145. https://doi.org/10.3991/ijet.v16i14.22685

[28] Salloum, S.A., Al-Emran, M., Habes, M., Alghizzawi, M., Ghani, M.A., Shaalan, K. (2021) What impacts the acceptance of e-learning through social media? An empirical study. Studies in Systems, Decision and Control, 335, pp. 419-431. https://doi.org/10.1007/978-3-03064987-6 24

Rojas, L.F.M., Jaimes, N.M. (2020) Canvas LMS and Collaborative work as a learning methodology in virtual environments. Iberian Conference on Information Systems and Technologies, CISTI, 2020-June, art. no. 9140885. https://doi.org/10.23919/cisti49556. $\underline{2020.9140885}$

[30] Meza, J.A.D., Castro, M.L.C., Vivas, R.V.J., Rueda, A.C.C. (2020) Collaborative learning tools used in virtual higher education programs: A sistematic review of literature in Iberoamerica. Iberian Conference on Information Systems and Technologies, CISTI, 2020-June, art. no. 9140901. https://doi.org/10.23919/cisti49556.2020.91409011

[31] Lukhmanova, G.K., Mishchenko, V.V., Chsherbovskikh, I., Yerzhanova, G.Z., Shmidt, M., Alimzhanova, Z.M. (2019) On the effectiveness of blended learning technologies in higher education. Opcion, 35 (Special Issue 19), pp. 3078-3086. 
[32] Solórzano-Restrepo, J., López-Vargas, O. (2019) Differential effect of a metacognitive scaffolding in a e-Learning environment over cognitive load, learning achievement and metacognitive consciousness. Suma Psicologica, 26 (1), pp. 37-45. https://doi.org/10.14349/ sumapsi.2019.v26.n1.5

[33] Zhang, Y., Zhang, P., Yang, H., Zhao, K., Han, C. (2021) Influencing Factors of Students' Online Learning Satisfaction During the COVID-19 Outbreak: An Empirical Study Based on Random Forest Algorithm. Lecture Notes in Computer Science (including subseries Lecture Notes in Artificial Intelligence and Lecture Notes in Bioinformatics), 12511 LNCS, pp. 103-114. https://doi.org/10.1007/978-3-030-66906-5 10

[34] Puška, A., Puška, E., Dragić, L., Maksimović, A., Osmanović, N. (2021). Students' Satisfaction with E-learning Platforms in Bosnia and Herzegovina. Technology, Knowledge and Learning, 26 (1), pp. 173-191. https://doi.org/10.1007/s10758-020-09446-6

[35] Bordel, B., Mareca, P. (2020) Results and Trends in educational MOOCs in the engineering area with MIRIADAX platform. A case study. Iberian Conference on Information Systems and Technologies, CISTI, 2020-June, art. no. 9140967. https://doi.org/10.23919/cisti49556. 2020.9140967

[36] Segura-Robles, A., Moreno-Guerrero, A.-J., Parra-González, M.-E., López-Belmonte, J. (2020) Review of research trends in learning and the internet in higher education. Social Sciences, 9 (6), art. no. 101. https://doi.org/10.3390/socsci9060101

[37] López-Belmonte, J., Segura-Robles, A., Moreno-Guerrero, A.-J., Parra-González, M.-E. (2021) Projection of e-learning in higher education: A study of its scientific production in web of science. European Journal of Investigation in Health, Psychology and Education, 11 (1), pp. 20-32. https://doi.org/10.3390/ejihpe11010003

[38] Hernández, R.; Fernández, C.; Baptista, P. Metodología de la Investigación, 6th Ed.; MC Graw Hill Education: Mexico, 2016.

[39] Shahnaz M. Alkhalil, Ahmad A. Manasrah, Loai M. Dabbour, Esra'a A. Bashayreh, Eman A. Abdelhafez \& Esraa G. Rababa. (2021) Pandemia de COVID-19 y el e-learning en instituciones de educación superior: Facultad de ingeniería y tecnología en la Universidad AlZaytoonah de Jordania como estudio de caso. Journal of Human Behavior in the Social Environment, 31: 1-4, 464-475. https://doi.org/10.1080/10911359.2020.1829243

\section{Authors}

Yersi Luis Huamán Romaní is a member of the College of Mathematicians of Peru, he has been teaching mathematics at the National Frontier University in the category of Associate since 2019, he also belongs to the American Mathematics Association. University professor since 2011 in different universities in Peru, researcher and editor of books in the area of mathematics. With ORCID code: https://orcid.org/0000-00017209-7727.

José Luis Estrada Pantia, graduated from the National San Antonio Abad del Cusco University, Master in the National Mayor de San Marcos University, Dean of America, member of the College of Mathematicians of Peru, teacher of mathematics and statistics at the National José María Arguedas University in the category of Associate since 2011; university professor since 2002 in different universities in Peru, researcher and editor of books in the area of mathematics and statistics. With ORCID code: https://orcid.org/0000-0002-6138-9043 (Email: ljestradap@gmail.com). 
Orlando Olivares Rivera, by profession a mathematician graduated from the National of San Antonio Abad de Cusco University (UNSAAC), is a member of the College of Mathematicians of Peru, professor in the Academic Department of Basic Sciences of the National José María Arguedas University (UNAJMA), from 2014 to the present, also with a master's degree in Statistics and Scientific Research from the Andean University of Cusco (UAC), researcher and editor of books in mathematics. With ORCID Code: https://orcid.org/0000-0001-9476-1211 (Email: orlando.olivaresriv@gmail.com)

Efrain Rodas Guizado is a member of the College of Mathematicians of Peru, master in Statistics and Scientific Research, is a professor of Mathematics and Statistics at the National José María Arguedas University in the category of Assistant since 2012. University professor in different universities in Peru, researcher and editor of books in the area of Mathematics and Statistics. With ORCID code: https://orcid.org/0000-00028862-3151 (Email: erguizado@gmail.com).

Frida Esmeralda Fuentes Bernedo, graduated from National San Agustín de Arequipa University, teacher at National José María Arguedas University-Andahuaylas in the category of Associate since 2017. University professor since 2006, researcher in Applied Mathematics. With ORCID code: https://orcid.org/0000-0002-8731-4621y (Email: friesfube@gmail.com).

Article submitted 2021-06-09. Resubmitted 2021-08-10. Final acceptance 2021-08-12. Final version published as submitted by the authors. 